\title{
Part Time Employment
}

National Cancer Institute

\section{Source}

National Cancer Institute. Part Time Employment. NCI Thesaurus. Code C75562.

Employment involving less than the standard or customary working time. 